\title{
Capital Control Measures: A New Dataset
}




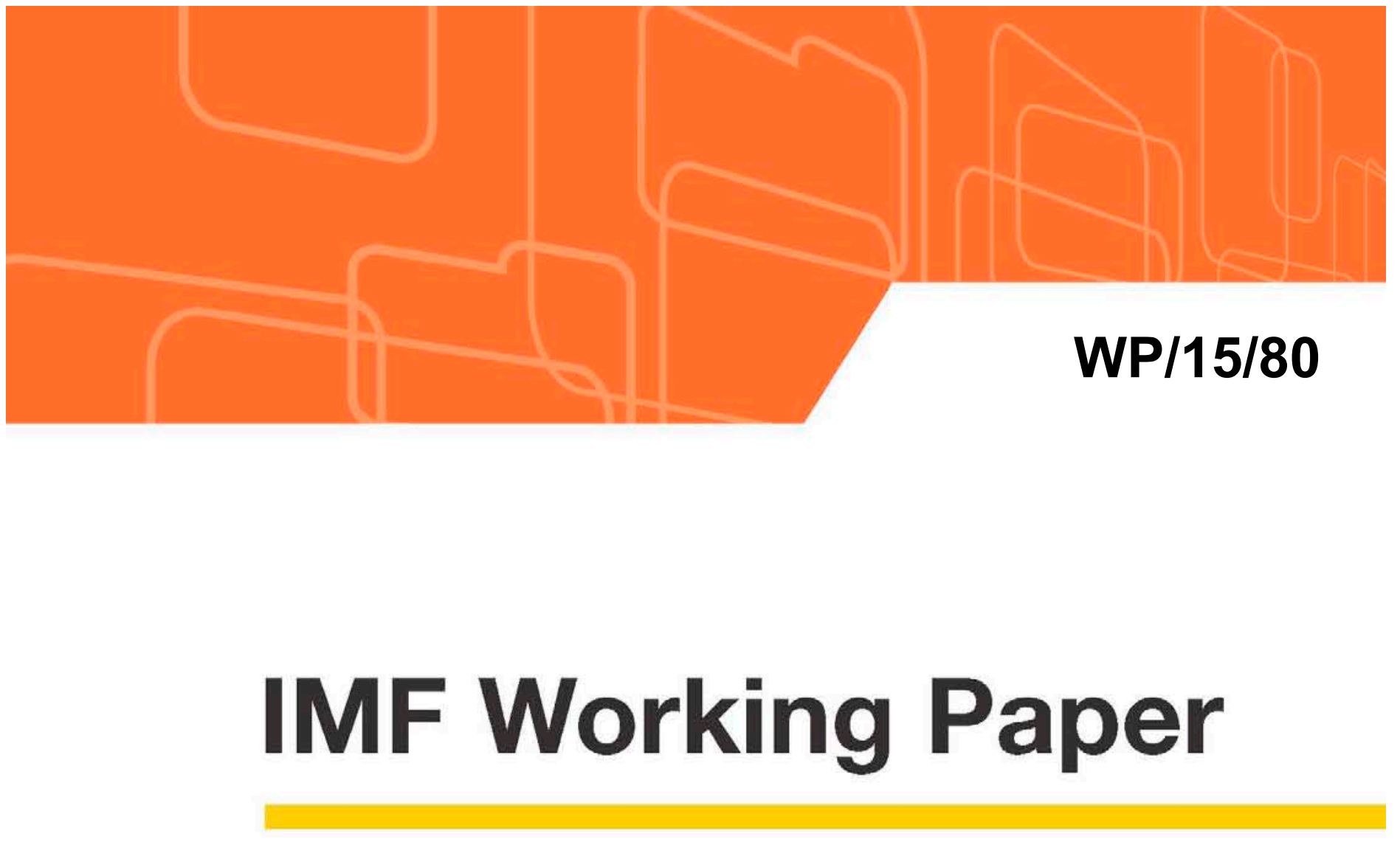

\section{Capital Control Measures: A New Dataset}

Andrés Fernández, Michael W. Klein, Alessandro Rebucci, Martin Schindler, and Martín Uribe 


\title{
IMF Working Paper
}

Institute for Capacity Development

\section{Capital Control Measures: A New Dataset ${ }^{1}$ \\ Prepared by Andrés Fernández, Michael W. Klein, Alessandro Rebucci, Martin Schindler, and Martín Uribe}

Authorized for distribution by Norbert Funke

April 2015

\begin{abstract}
This Working Paper should not be reported as representing the views of the IMF. The views expressed in this Working Paper are those of the author(s) and do not necessarily represent those of the IMF or IMF policy. Working Papers describe research in progress by the author(s) and are published to elicit comments and to further debate.
\end{abstract}

\begin{abstract}
This paper presents a new dataset of capital control restrictions on both inflows and outflows of 10 categories of assets for 100 countries over the period 1995 to 2013 . Building on the data in Schindler (2009) and other datasets based on the analysis of the IMF's Annual Report on Exchange Arrangements and Exchange Restrictions (AREAER), this dataset includes additional asset categories, more countries, and a longer time period. The paper discusses in detail the construction of the dataset and characterizes the data with respect to the prevalence and correlation of controls across asset categories and between controls on inflows and controls on outflows, the aggregation of the separate categories into broader indicators, and the comparison of this dataset with other indicators of capital controls.

JEL Classification Numbers: F3, F36, F38

Keywords: capital control measures, capital flows; international financial integration Author's E-Mail Address: andresf@iadb.org, michael.klein@tufts.edu, arebucci@jhu.edu, mschindler@imf.org, martin.uribe@,columbia.edu

\footnotetext{
${ }^{1}$ Author affiliations: Fernández: InterAmerican Development Bank; Klein: Fletcher School, Tufts University \& NBER; Rebucci: Carey Business School, Johns Hopkins University; Schindler: International Monetary Fund \& Joint Vienna Institute; Uribe: Columbia University \& NBER. We thank Javier Caicedo for excellent research assistance. The information and opinions presented in this work are entirely those of the authors, and express or imply no endorsement by the Inter-American Development Bank, the International Monetary Fund, the Board of Executive Directors of either institution, or the countries they represent. The dataset is available for download at http://www.nber.org/data/international-finance/.
} 
Contents

PAGE

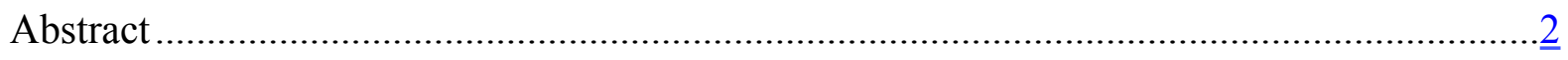

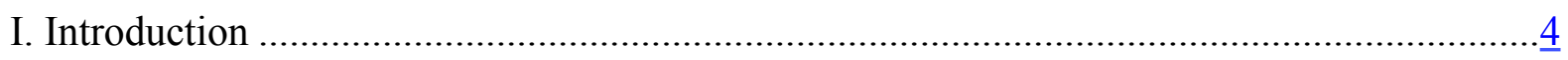

II. Constructing the Capital Control Indicators.....................................................................

III. Characteristics of the Capital Control Indicators ...............................................................

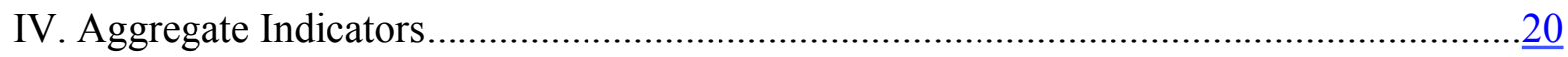

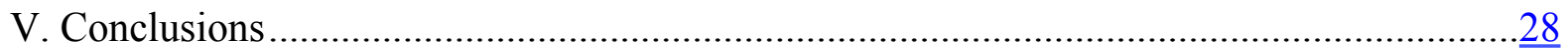

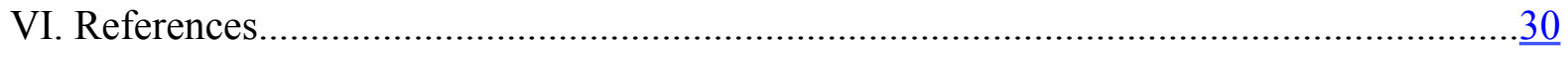

\section{TABLES}

Table 1: Asset and Transaction Categories for Capital Control Measures...............................10

Table 2: Countries In Data Set, By Income Groups, With Open/Gate/Wall Category ............14

Table 3: Prevalence of Controls, 100 Countries, 1995 - 2013, by Asset Sub-Categories........16

Table 4: Cross-Category Correlations, All 100 Countries, 1995-2013, ................................ 17

Table 5A: Cross-Category Correlations, 47 Gate Countries, 1995-2013 ……………...........19

Table 5B: Cross-Category Correlations, 53 Open and Wall Countries, 1995-2013 .................19

Table 6: Correlation between Nine-Asset Aggregate Capital Controls and Excluded Asset

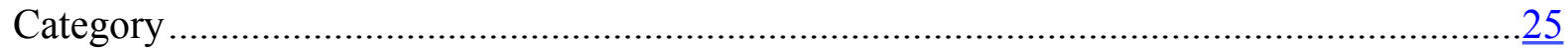

Table 7: Correlations among Aggregate Capital Controls Measures ..................................... 26

\section{Figures}

Figure 1: Proportion of Observations with Controls..........................................................

Figure 2A: Average Controls on Inflows by Income Groups..............................................

Figure 2B: Average Controls on Outflows by Income Groups …………………………....22

Figure 3: Inflow Controls vs. Outflow Controls ...................................................................23

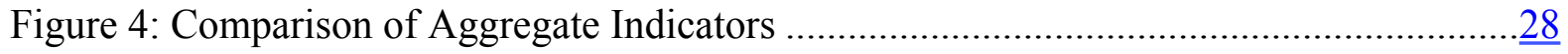

\section{REFERENCES}

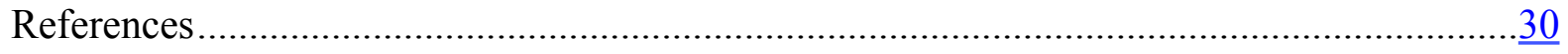




\section{INTRODUCTION}

International capital flows are central to international macroeconomics. The interaction between the monetary and exchange rate policies of a country depends upon its stance towards capital mobility, as described by the policy trilemma. The ability of a government and its citizens to borrow and lend abroad allows domestic investment to diverge from domestic savings, which can promote economic efficiency and growth. In addition, international portfolio diversification is a potentially important means by which individuals can smooth consumption and undertake risky investments that would otherwise be unattractive. On a less salutary note, international capital flows are also blamed for being an important vector through which economic disturbances are spread across countries, or as a means by which investors prompt a sudden stop that causes an economy to crash.

This range of potential outcomes from the international trade in assets has contributed to varying attitudes towards capital flows, as well as towards capital controls. Controversies over international capital flows have a long history. For example, in 1920 J.M. Keynes wrote elegiacally of a pre-war time when a person could "...adventure his wealth in the natural resources and new enterprises of any quarter of the world..." (The Economic Consequences of the Peace, Chapter II). But he took a very different tone in a 1933 speech in Dublin when he stated “... let goods be home-spun whenever it is reasonable and conveniently possible and, above all, let finance be national."

Keynes' negative view of international capital flows in the midst of the Great Depression echoes through time in more contemporary calls for capital controls, especially in the wake of the recent current economic and financial crisis. While capital controls were pervasive during the Bretton Woods era, they were reduced or eliminated beginning in the late 1970s, and, increasingly, in the 1980s and 1990s. The title of Rudiger Dornbusch's 1998 article "Capital Controls: An Idea Whose Time is Gone" reflects a broad consensus at that time. But attitudes began to shift in response to the economic crises in the late 1990s (Rodrik, 1998; Bhagwati, 1998). These changes were far from a fringe view; in 2002, Kenneth Rogoff, then serving as the Chief Economist and Director of Research of the International Monetary Fund wrote in the

\footnotetext{
${ }^{2}$ Quoted in Skidelsky (1992: 477).
} 
Fund's publication Finance and Development "These days everyone agrees that a more eclectic approach to capital account liberalization is required."

The Great Recession has spurred a further reevaluation of the appropriate role of capital controls. Countries as diverse as Brazil and Switzerland considered (and in the case of Brazil, implemented) controls on inflows in the face of currency appreciation, while Iceland introduced controls on outflows at the time of its crisis. A number of recent IMF staff studies and policy papers accept the use of capital controls as part of a country's "policy toolkit" under certain circumstances, a shift that The Economist magazine dubbed "The Reformation." 3 Even stronger calls for a greater role for capital controls include Jeanne, Subramanian and Williamson (2012) and Rey (2013). Some of these policy prescriptions are consistent with a new branch of theoretical research in which capital controls contribute to financial stability and macroeconomic management. ${ }^{4}$ The empirical research of others, however, emphasizes the ineffectiveness and potential costs of capital controls. ${ }^{5}$

The evolving nature of the debate on capital controls, and the policy prescriptions that follow, suggest that further careful empirical analysis is needed. One challenge facing empirical researchers in this area concerns the availability of indicators of capital controls. Although some empirical research addresses this challenge by considering the experience of a specific country, ${ }^{6}$ broader, cross-country analyses require panel data reflecting the experience of a range of countries. While a number of panel data sets exist, those with broad time and/or country coverage are typically hampered by a lack of granularity (for example, Chinn and Ito, 2006, and Quinn, 1997), often providing little information beyond a broad index of "capital account

\footnotetext{
${ }^{3}$ Examples of IMF studies include Ostry et al. (2010) and Ostry et al. (2011). The article in The Economist appeared in the April 7, 2011 issue.

${ }^{4}$ For just a few examples, see Korinek (2010), Bianchi (2011), Farhi and Werning (2012), Jeanne (2012), SchmittGrohé and Uribe (2012), and Benigno et al. (2014).

${ }^{5}$ See, for example, Forbes (2007), Binici, Hutchison and Schindler (2010), Klein (2012), Prati, Schindler and Valenzuela (2012), and Klein and Shambaugh (2015).

${ }^{6}$ See, for example, studies of the experiences of Chile by DeGregorio, Edwards and Valdés (2000) and Forbes (2007), and of Brazil by Forbes et al. (2012).
} 
openness," while others with finer granularity have been more limited in terms of sample coverage (such as Schindler, 2009, Miniane, 2004, and Tamirisa, 1999). ${ }^{7}$

In this paper, we introduce a new dataset based on the methodology in Schindler (2009), but including more countries, more asset categories and more years. In particular, the new dataset reports the presence or absence of capital controls, on an annual basis, for 100 countries over the period 1995 to 2013. As discussed in greater detail below, this dataset revises, extends, and widens the data set originally developed by Schindler (2009), and later expanded by Klein (2012) and Fernández, Rebucci and Uribe (2014). This dataset's wide range of countries and its coverage of a period of changing policies make it a potentially important resource for research and policy. ${ }^{8}$

In particular, a distinguishing and important feature of these data is that the information on capital controls is disaggregated both by whether the controls are on inflows or outflows, and by 10 different categories of assets. This allows for a more detailed analysis of capital controls, including an examination of the co-movements of controls on different types of assets, and on the co-movements of controls on inflows and outflows, as well as the construction of aggregate measures of controls that are well targeted to the specific nature of the topic being studied. Variations of such aggregate measures across time serve as one indicator of the intensity of the application of restrictions on international capital movements.

The next section of the paper discusses the methods used to develop this dataset from annual information published by the IMF. In Section 3 we discuss some statistics of our disaggregated dataset, including the correlation across categories of assets and directions of transactions (that is, controls on inflows or on outflows). Section 4 discusses issues related to aggregating the asset categories and also compares an aggregated index of our data with two aggregate indicators that are commonly used in panel estimation, those first introduced in Quinn (1997) and in Chinn and Ito (2006). We offer some concluding comments in Section 5.

\footnotetext{
${ }^{7}$ See Quinn, Schindler, and Toyoda (2011) for a comprehensive review of existing de jure measures.

8 The dataset is publicly available for download at the National Bureau of Economic Research website (http://www.nber.org/data/international-finance/) or at request from the authors.
} 


\section{Constructing the Capital Control Indicators}

Cross-country time series of capital controls typically draw from the IMF's Annual Report on Exchange Arrangements and Exchange Restrictions (AREAER). ${ }^{9}$ The capital control measures presented in this paper are also based on the de jure information from this source. ${ }^{10}$ There was a fundamental change in the reporting on capital controls beginning with the 1996 volume of the AREAER (providing information for conditions in 1995) when it began including more detailed information both across a disaggregated set of assets and by distinguishing between controls on outflows and controls on inflows; thus our data series begin in 1995 and currently include data through 2013. ${ }^{11}$ In this section we describe the dataset we have constructed and discuss the methods we have taken to translate the narrative in the annual volumes into a panel dataset.

The present work revises, extends, and widens the data set originally developed by Schindler (2009), and later expanded by Klein (2012) and Fernández, Rebucci and Uribe (2014). Schindler's dataset covers 91 countries over the period 1995 to 2005, and considers restrictions on inflows and outflows over six asset categories, namely, equity, bonds, money market, collective investment, financial credit, and foreign direct investment. Klein (2012) extends Schindler's dataset to include the period 2006 to 2010 but limits the coverage to 44 countries and restrictions on inflows. Fernandez, Rebucci and Uribe (2014) further extend the dataset to the year 2011 for the original 91 countries in Schindler (2009). They also consider restrictions on capital inflows and outflows.

The dataset discussed in this paper extends currently available data in three dimensions; asset categories, countries, and sample period. The four new asset categories are derivatives, commercial credit, financial guarantees, and real estate. Derivatives are of particular interest,

\footnotetext{
${ }^{9}$ The early works that use the AREAER to create panel data sets of capital controls include Grilli and MilesiFerretti (1995), Quinn (1997) and Chinn and Ito (2006).

${ }^{10}$ That is, the measures capture legal restrictions, but not whether or to what extent they are enforced. One difficulty in trying to construct empirically-based de facto indicators of capital account restrictions is that there is not a clear benchmark of the gross capital flows consistent with free capital mobility. Furthermore, de facto indicators based on the equalization of rates of return would assume efficient markets, and require making assumptions about investors' expectations and preferences as well as the correlations of asset returns with other measures of risk.

11 There is very limited coverage for the years 1995 and 1996 for one category of assets, controls on bonds with maturity of greater than one year, and so the data series for this asset begins in 1997.
} 
given their increasing role in international transactions (Lane and Milesi-Ferretti, 2007). The nine new countries were selected through a population-based criterion, bringing the total number of countries to $100 .^{12}$ The sample period has been extended to cover the period 1995 to 2013 .

This paper also provides the specific set of rules used for coding the narrative in the AREAER reports in order to generate the data. These rules are explained in detail below, and in even greater detail in a technical appendix available from the authors. The rules build on those used by Schindler (2009). We clarify the rules, and provide explicit criteria, in order to facilitate future updates of the dataset. These rules are also used to revise some of the observations in Schindler's original dataset in order to ensure a harmonization of those data with the new observations included in this expanded dataset. ${ }^{13}$

The AREAER reports the presence of rules and regulations for international transactions by asset categories. The 10 asset categories in our dataset allow us to capture a large proportion of global cross-national asset holdings. The categories, with their two-letter abbreviations, are the following: ${ }^{14}$

1. Money market instruments, which includes securities with an original maturity of one year or less, in addition to short-term instruments like certificates of deposit and bills of exchange, among others. (mm)

2. Bonds or other debt securities with an original maturity of more than one year. (bo)

3. Equity, shares or other securities of a participating nature, excluding those investments for the purpose of acquiring a lasting economic interest which are addressed as foreign direct investment. (eq)

\footnotetext{
${ }^{12}$ The nine added countries were those with the largest populations in 2012 (according to the World Development Indicators) that were not in the original Schindler data set, but were included in the AREAER. These countries are Algeria, Colombia, Ethiopia, Iran, Myanmar, Nigeria, Poland, Ukraine and Vietnam.

${ }^{13}$ Specifically, whenever a discrepancy arose in a particular asset/country category between Schindler's original data set and ours in 2005 (the last year of Schindler's dataset), the data was revised for that category in that year and backwards until no discrepancy was detected. If there was no discrepancy in 2005 then there was no revision backwards for that country/asset subcategory. In total, only 145 observations (less than one percent of the original dataset) was modified. These observations are listed in the master data file.

${ }^{14}$ Where applicable, the notation follows that in Schindler (2009).
} 
4. Collective investment securities such as mutual funds and investment trusts. (ci)

5. Financial credit and credits other than commercial credits granted by all residents, including banks, to nonresidents, or vice versa. (fc)

6. Derivatives, which includes operations in rights, warrants, financial options and futures, secondary market operations in other financial claims, swaps of bonds and other debt securities, and foreign exchange without any other underlying transaction. (de)

7. Commercial Credits for operations directly linked with international trade transactions or with the rendering of international services. (cc)

8. Guarantees, Sureties and Financial Back-Up Facilities provided by residents to nonresidents, and vice versa, which includes securities pledged for payment or performance of a contract — such as warrants, performance bonds, and standby letters of credit - and financial backup facilities that are credit facilities used as a guarantee for independent financial operations. (gs)

9. Real Estate transactions representing the acquisition of real estate not associated with direct investment, including, for example, investments of a purely financial nature in real estate or the acquisition of real estate for personal use. (re)

10. Direct investment accounts for transactions made for the purpose of establishing lasting economic relations both abroad by residents and domestically by nonresidents. (di)

The AREAER distinguishes across types of transactions according to the residency of the buyer or the seller, and whether the transaction represents a purchase or a sale or issuance. For five asset categories, Money Market, Bonds, Equities, Collective Investments and Derivatives, there are four categories of transactions controls: two categories of controls on inflows, including Purchase Locally by Non-Residents (plbn) and Sale or Issue Abroad by Residents (siar); and two categories of controls on outflows, which are Purchase Abroad by Residents (pabr) and Sale or Issue Locally by Non-Residents (siar). The Real Estate category includes the inflow transaction category plbn and the outflow control transaction categories pabr and Sale Locally by NonResidents (slbn). There is only a broader classification of inflow controls or outflow controls for 
the three categories of Financial Credits (fci and fco), Commercial Credits (cci and cco), and Guarantees, Sureties and Financial Backup Facilities (gsi and gso). Direct Investment includes the categories of controls on inflows (dii), controls on outflows (dio), and controls on the Liquidation of Direct Investment (ldi) which captures controls on capital inflows or outflows from the liquidation of direct investment abroad or domestically. Thus, in its most disaggregated format, our dataset provides information on 32 transaction categories. Table 1 summarizes those categories.

Table 1. Asset and Transaction Categories for Capital Control Measures

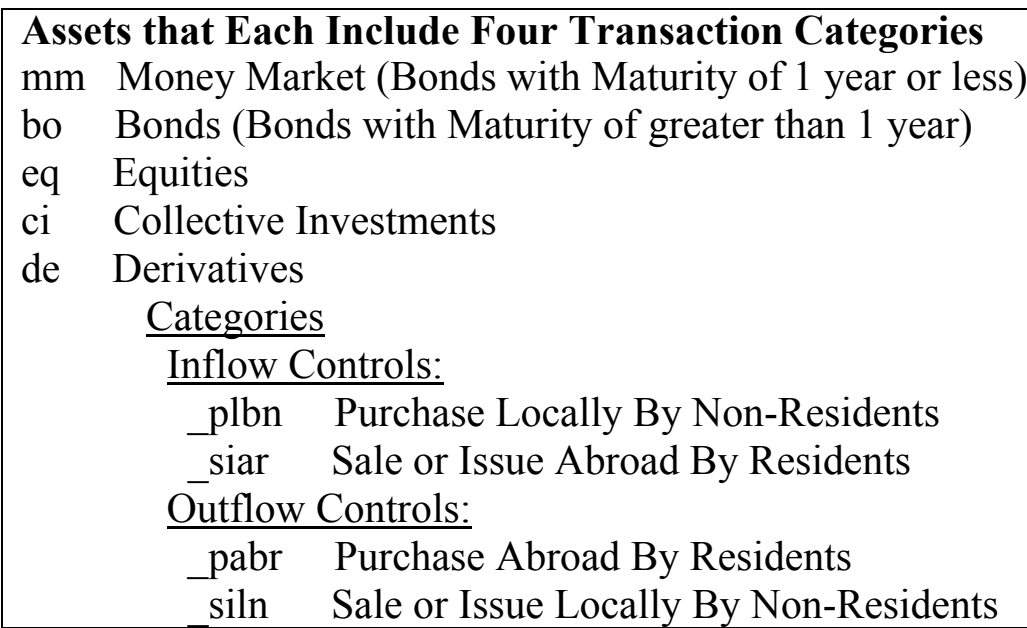

Assets that Include Only Inflow (i) or Outflow (o) Categories

gsi \& gso Guarantees, Sureties \& Financial Backup Facilities

fci \& fco Financial Credits

cci \& cco Commercial Credits

\section{Real Estate}

Re Real Estate

$\underline{\text { Categories }}$

Outflow

_pabr Real Estate Purchase Abroad By Residents

slbn Sale Locally By Non-Residents

Inflow

plbn Real Estate Purchase Locally By Non-Residents

\section{Direct Investment}

dii Direct Investment Controls on Inflows

dio Direct Investment Controls on Outflows

ldi Direct Investment Controls on Liquidation

The four series for each of the five categories of assets $\mathrm{mm}$, bo, eq, ci, and de have the suffixes plbn,_siar, _pabr or_siln. Real Estate is represented by the three series re_pabr, re_slbn and re_plbn. The suffixes for the three series gs, fc, and cc represent inflow or outflow controls (e.g., gsi and gso, respectively). 
We use the narrative description in the AREAER to determine whether or not there are restrictions on international transactions, with 1 representing the presence of a restriction and 0 representing no restriction. ${ }^{15}$ This requires a set of rules on interpreting the information presented in these narratives. We formulated rules consistent with those used for the original Schindler (2009) dataset, developing them when further clarification was warranted. The key points of these rules are: ${ }^{16}$

1. The annual information from the AREAER reports comes with three columns; the first listing the asset subcategory, the second containing a YES (that is, a restriction is in place), a NO, or no entry, and the third including narrative information. When coding each subcategory we first look at the information in both columns two and three of the reports and follow these criteria:

i. If there is no narrative information in the third column we code on the basis of the information in the second column where we assign a 0 for NO and a 1 for YES.

ii. If there is information in the third column we code based on the narrative information in that column.

2. A control is deemed to be in place when the narrative information alludes to a transaction explicitly requiring "authorization," "approval," "permission," or "clearance" from a public institution. However, a requirement of "reporting," "registration," or "notification" is not counted as constituting a control.

\footnotetext{
${ }^{15}$ The AREAER narrative is limited to either n.r. or $n . a$. in about 2.8 percent of the cases in our data. The entry n.a. is used by the IMF "when it is unclear whether a particular category or measure exists - because pertinent information is not available at the time of publication." (IMF, 2011: page ?) The entry n.r. is used when "members have provided the IMF staff with information that a category or an item is not regulated." In addition, our dataset has the category d.n.e. that represents "does not exist" to document the cases where there is no information whatsoever, but this appears only 15 times in the entire dataset ( 0.03 percent of the dataset). The dataset available on line retains the n.r., n.a., and d.n.e. entries, but in the statistics presented in this paper we set to missing an entry with any of these three classifications.

${ }^{16}$ A more detailed description of our rules and guiding principles is contained in the Technical Appendix.
} 
3. A quantity restriction on any investment (e.g. in the form of "ceiling") is coded as a control. In addition, an explicit allusion to a restriction for "prudential" considerations is deemed to be a control.

4. Restrictions on a particular asset that prevent capital flows from and into specific countries on the basis of political or national security reasons are not considered capital controls.

5. When there is a restriction specifically for transactions for only one sector (except the financial system or for pension funds) and/or when that restriction is for an area reserved for state control (such as defense, security, central banking, etc.) that restriction is not categorized as a capital control. If, on the other hand, the restriction does not specify which areas other than defense are reserved for state control, then the restriction is categorized as a control. Restrictions are counted as a capital control if they cover more than one sector in which private entrepreneurship is common, and these restrictions are deemed to have a macroeconomic impact.

There are a variety of ways to aggregate these data series in order to obtain a smaller set of indicators than the full set of 32 categories presented in Table 1. The most basic aggregation is to have indicators of inflow controls and outflow controls for the ten asset categories. This does not require any aggregation for the asset categories of Commercial Credits, Financial Credits or Guaranties, Sureties and Financial Backup Facilities since the dataset only includes their inflow (cci, fci and gsi) and outflow (cco, fco and gso) categories, and the value of each of these indicators will be either 0 or 1 . We do not aggregate Direct Investment on Inflows, Outflows and Controls on Liquidation of Direct Investment in this paper, but keep the three categories separate, denoting them as dii, dio, and ldi, all of which will have values of either 0 or 1. In the case of Real Estate, there is only one inflow category (which we denote rei), but there would need to be an aggregation of re_pabr and re_slbn to obtain a single, aggregate outflow category (which we call reo).

The aggregation scheme that we follow to obtain a single outflow category for Real Estate, as well as both an inflow indicator and an outflow indicator for the other five asset categories that each have two inflow and outflow categories, is to construct indices that represent the average of the inflow or outflow indicators. For each of these 11 asset categories, the 
aggregate inflow index is the average of the 0 or 1 in Purchased Locally by Nonresidents and Sale or Issue Abroad by Residents, and the aggregate outflow index is the average of the 0 or 1 in Purchased Abroad by Residents and Sale or Issue Locally by Non-Residents (or, for Real Estate, Sale Locally by Non-Residents). Thus the values of mmi, mmo, boi, boo, eqi, eqo, cii, cio, dei, deo and reo will be $0,1 / 2$ or $1 .{ }^{17}$ For these categories, one could interpret an entry of one as representing greater intensity of controls than an entry of $1 / 2$.

\section{Characteristics OF THE CAPITAl Control IndiCators}

In this section, we present some characteristics of the capital control data. We begin by considering the properties of inflow and outflow controls for the ten asset categories. We then discuss aggregating these series into broader indicators that reflect the average level of controls for the full set of assets, or for subsets consisting of two or more categories. We conclude this section with an estimation of the correlation between our broad capital control indicator and two other popular indicators of aggregate capital controls.

The dataset covers 100 countries over the period 1995 to 2013. The list of countries, by World Bank Income Group, is presented in Table 2. As shown in that table, there are 42 high income countries, 32 upper middle income countries, 18 lower middle income countries, and eight low income countries.

This table also includes Klein's (2012) classification of a country as Open, Gate or Wall. There will be further discussion of this classification below, but the basic point is that an Open country has virtually no capital controls on any asset category over the sample period, a Wall country has pervasive controls across all, or almost all, categories of assets and a Gate country uses capital controls episodically.

We begin by considering the prevalence of controls, by asset/direction categories (where direction refers to whether the control is on inflows or outflows). The detailed nature of our data set permits an examination of differences across these categories. These differences could be important because the effects of policies may vary depending upon whether controls are targeted towards inflows or outflows of particular classes of assets. Broad indicators of capital controls

\footnotetext{
${ }^{17}$ When there is a missing value in one of the two inflow or outflow subcategories (see footnote 12), we score the aggregate inflow or outflow entry with the value taken by the remaining subcategory.
} 
that do not distinguish across asset categories, or even between controls on inflows and controls on outflows, will mask potentially important variations in the types of controls.

Figure 1 shows the prevalence of controls across 20 asset/direction categories. In this figure, no distinction is made between a value of $1 / 2$ and 1 ; instead, each is treated equally as a control. The prevalence of controls ranges from 18 percent of observations (for liquidation of direct investment), to 25 percent (for inflow controls on Guarantees, Sureties and Financial Backup Facilities) to 50 percent or greater (for inflow controls on Real Estate and outflow controls on Money Market Instruments, Bonds, Equities, Collective Investments, and Derivatives). The figure also demonstrates that, with the exceptions of Real Estate and Direct Investment, there is a higher prevalence of controls on outflows than on inflows.

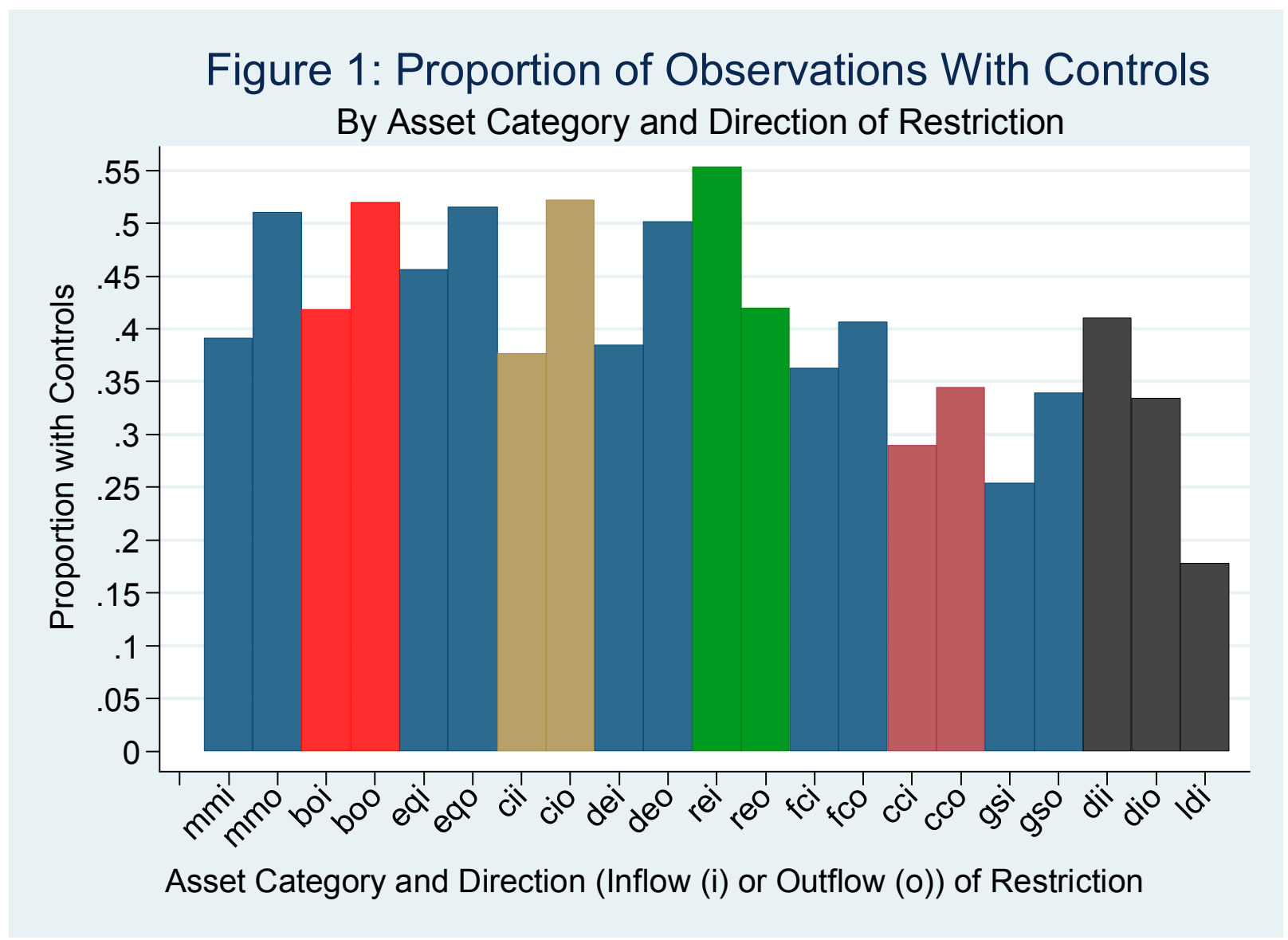


Table 2. Countries In Data Set, By Income Groups, With Open/Gate/Wall Category

\begin{tabular}{|c|c|c|c|c|c|}
\hline \multicolumn{2}{|l|}{ High (42) } & \multicolumn{2}{|l|}{ Upper Middle (26) } & \multicolumn{2}{|c|}{ Lower Middle \& Low (32) } \\
\hline Australia & Gate & Algeria & Wall & Bangladesh* & Gate \\
\hline Austria & Open & Angola & Wall & Bolivia & Gate \\
\hline Bahrain & Gate & Argentina & Gate & Burkina Faso* & Gate \\
\hline Belgium & Open & Brazil & Gate & Cote d'Ivoire & Wall \\
\hline Brunei Darussalam & Open & Bulgaria & Gate & Egypt & Open \\
\hline Canada & Open & China & Wall & El Salvador & Open \\
\hline Chile & Gate & Colombia & Gate & Ethiopia* & Gate \\
\hline Cyprus & Gate & Costa Rica & Open & Georgia & Open \\
\hline Czech Republic & Gate & Dominican Republic & Gate & Ghana & Gate \\
\hline Denmark & Open & Ecuador & Gate & Guatemala & Open \\
\hline Finland & Open & Hungary & Gate & India & Wall \\
\hline France & Open & Iran & Gate & Indonesia & Gate \\
\hline Germany & Gate & Jamaica & Gate & Kenya* & Gate \\
\hline Greece & Open & Kazakhstan & Gate & Kyrgyz Republic & Gate \\
\hline Hong Kong & Open & Lebanon & Gate & Moldova & Gate \\
\hline Iceland & Gate & Malaysia & Wall & Morocco & Wall \\
\hline Ireland & Open & Mauritius & Open & Myanmar* & Gate \\
\hline Israel & Gate & Mexico & Gate & Nicaragua & Open \\
\hline Italy & Open & Panama & Open & Nigeria & Gate \\
\hline Japan & Open & Peru & Open & Pakistan & Wall \\
\hline Korea & Gate & Romania & Gate & Paraguay & Open \\
\hline Kuwait & Gate & South Africa & Gate & Philippines & Wall \\
\hline Latvia & Open & Thailand & Gate & Sri Lanka & Wall \\
\hline Malta & Gate & Tunisia & Wall & Swaziland & Wall \\
\hline Netherlands & Open & Turkey & Gate & Tanzania* & Wall \\
\hline New Zealand & Open & Venezuela & Gate & Togo* & Wall \\
\hline Norway & Open & & & Uganda* & Gate \\
\hline Oman & Open & & & Ukraine & Wall \\
\hline Poland & Gate & & & Uzbekistan & Wall \\
\hline Portugal & Gate & & & Vietnam & Gate \\
\hline Qatar & Open & & & Yemen & Open \\
\hline Russia & Gate & & & Zambia & Open \\
\hline Saudi Arabia & Gate & & & \multirow{10}{*}{\multicolumn{2}{|c|}{$\begin{array}{c}*=\text { Low Income rather than } \\
\text { Lower Middle Income }\end{array}$}} \\
\hline Singapore & Open & & & & \\
\hline Slovenia & Gate & & & & \\
\hline Spain & Open & & & & \\
\hline Sweden & Open & & & & \\
\hline Switzerland & Gate & & & & \\
\hline U.A.E. & Gate & & & & \\
\hline United Kingdom & Open & & & & \\
\hline United States & Open & & & & \\
\hline Uruguay & Open & & & & \\
\hline \multicolumn{6}{|c|}{ Open (36) / Gate (48) / Wall (16) } \\
\hline $24 / 18 / 0$ & & $4 / 17 / 5$ & & $8 / 13 / 11$ & \\
\hline
\end{tabular}

Note: Following Klein (2012), "Open" ("Walls") countries have, on average, capital controls on less than 10 percent (more than 70 percent) of their transactions subcategories over the sample period and do not have any years in which controls are on more than 20 percent (less than 60 percent) of their transaction subcategories. "Gate" countries are neither Walls nor Open. 
A more detailed analysis by asset/direction category is presented in Table 3. The first set of columns shows the average control values $(0,1 / 2$ or 1$)$ for those eleven asset/direction categories that have two components for inflows or outflows, and the second set of columns shows the number of cases where controls are absent or present for the ten asset/direction categories that have only one component each for inflows and outflows. The final row of the second column shows that overall, 40 percent of the observations represent cases in which there are capital controls. For the asset/direction categories that can take the value $0,1 / 2$ or 1 , there are more observations of 1 than of $1 / 2$ (the difference is 26 percent of observations versus 20 percent).

Table 3. Prevalence of Controls, 100 Countries, 1995 - 2013, by Asset Sub-Categories

\begin{tabular}{|c|c|c|c|c|c|c|c|c|c|c|}
\hline & 0 & 0.5 & 1 & Total & \begin{tabular}{|l} 
Pr. \\
Cntrl \\
\end{tabular} & & 0 & 1 & Total & $\begin{array}{l}\text { Pr. } \\
\text { Cntrl }\end{array}$ \\
\hline $\mathrm{mmi}$ & 1,143 & 346 & 388 & 1,877 & \begin{tabular}{|l|l|}
0.39 \\
\end{tabular} & fci & 1,205 & 685 & 1,890 & 0.36 \\
\hline $\mathrm{mmo}$ & 917 & 367 & 589 & 1,873 & 0.51 & fco & 1,119 & 767 & 1,886 & 0.41 \\
\hline boi* & 980 & 378 & 327 & 1,685 & 0.42 & cci & 1,337 & 546 & 1,883 & 0.29 \\
\hline boo* & 807 & 356 & 517 & 1,680 & 0.52 & $\mathrm{cco}$ & 1,225 & 644 & 1,869 & 0.34 \\
\hline eqi & 1,024 & 459 & 399 & 1,882 & 0.46 & gsi & 1,384 & 471 & 1,855 & 0.25 \\
\hline eqo & 914 & 388 & 584 & 1,886 & 0.52 & gso & 1,227 & 631 & 1,858 & 0.34 \\
\hline cii & 1,152 & 360 & 335 & 1,847 & 0.38 & dii & 1,121 & 779 & 1,900 & 0.41 \\
\hline cio & 892 & 398 & 577 & 1,867 & 0.52 & dio & 1,246 & 625 & 1,871 & 0.33 \\
\hline dei & 1,073 & 219 & 452 & 1,744 & 0.38 & ldi & 1,546 & 334 & 1,880 & 0.18 \\
\hline deo & 890 & 310 & 585 & 1,785 & 0.50 & rei & 828 & 1,034 & 1,862 & 0.55 \\
\hline reo & 1,084 & 395 & 388 & 1,867 & 0.42 & Total & 23,469 & $15,134^{\dagger}$ & 38,603 & 0.40 \\
\hline \multicolumn{11}{|c|}{$\begin{array}{l}\text { Pr. Cntrl. = Proportion of observations with controls (i.e. either } 1 / 2 \text { or } 1 \text { ) } \\
\mathrm{i}=\text { control on inflows. _o = control on outflows } \\
\mathrm{mm}-\text { Money Market Instruments (Debt instruments with maturity } 1 \text { year or less) } \\
\text { bo - Bonds (Debt instruments with maturity greater than } 1 \text { year) } \\
\text { eq - Equities ci }- \text { Collective Investments de }- \text { Derivatives re }- \text { Real Estate } \\
\text { fc - Financial Credits cc }- \text { Commercial Credits gs - Guaranties \& Sureties } \\
\text { di - Direct Investment ldi - liquidation of direct investment }\end{array}$} \\
\hline
\end{tabular}

The detailed nature of our dataset enables us to consider, along with differences in the prevalence of controls across asset/direction categories, the correlation of controls across these categories. ${ }^{18}$ This is of interest for a number of reasons, including how governments choose to

18 The correlations are across all observations, that is, across all pairs $\mathrm{x}(t), \mathrm{y}(t)$, where $\mathrm{x}$ and $\mathrm{y}$ represent asset/direction categories and $t$ represents the time period. Correlations will be missing if the variance of an indicator is zero, but, in practice, there are relatively few instances of this, even among the Open and Walls

(continued...) 
pair controls across asset categories or between those on inflows and those on outflows, and whether such pairings strengthen the overall effect of policies. Table 4 presents correlations across the 10 asset categories that are listed in its rows and columns. The diagonal cells of the table show the correlation between inflows and outflows for each asset category; for example the correlation between mmi and mmo is 0.78 and the correlation between eqi and eqo is 0.72 . The upper triangular cells of the table show the correlations across asset categories for inflow controls; for example, the correlation between eqi and cii is 0.70 . The lower triangular cells of the table show the correlations across asset categories for outflow controls; for example, the correlation between gso and cco is 0.74 . The 100 entries in this table are color coded, with red cells representing correlations between 0.80 and 1.00, green cells representing correlations between 0.60 and 0.69 , turquoise cells representing correlations between 0.40 and 0.59 , yellow cells representing correlations between 0.20 and 0.39 , and no color highlighting for cells with correlations less than 0.20 .

Table 4. Cross-Category Correlations, All 100 Countries, 1995-2013

\begin{tabular}{|c|c|c|c|c|c|c|c|c|c|c|}
\hline & $\mathrm{mm}$ & bo & eq & $\mathrm{ci}$ & $\mathrm{de}$ & re & fc & $\mathrm{cc}$ & gs & Di \\
\hline $\mathrm{Mm}$ & 0.78 & 0.74 & 0.69 & 0.78 & 0.74 & 0.22 & 0.59 & 0.44 & 0.46 & 0.40 \\
\hline Bo & 1.82 & 0.74 & 0.70 & 0.66 & 0.67 & 0.21 & 0.54 & 0.37 & 0.46 & 0.40 \\
\hline $\mathrm{Eq}$ & 0.83 & 0.87 & 0.72 & 0.70 & 0.61 & 0.37 & 0.54 & 0.40 & 0.50 & 0.55 \\
\hline $\mathrm{Ci}$ & 87 & 0.83 & 0.85 & 0.75 & 0.72 & 0.21 & 0.63 & 0.51 & 0.56 & 0.49 \\
\hline De & .84 & 0.80 & 0.80 & 0.80 & 0.86 & 0.16 & 0.60 & 0.41 & 0.47 & 0.32 \\
\hline $\mathrm{Re}$ & 0.69 & 0.64 & 0.66 & 0.67 & 0.69 & 0.30 & 0.17 & 0.19 & 0.18 & 0.29 \\
\hline $\mathrm{Fc}$ & 0.69 & 0.64 & 0.67 & 0.66 & 0.69 & 0.63 & 0.62 & 0.67 & 0.62 & 0.37 \\
\hline $\mathrm{Cc}$ & 0.64 & 0.55 & 0.60 & 0.58 & 0.65 & 0.58 & 0.70 & 0.58 & 0.51 & 0.36 \\
\hline Gs & 0.64 & 0.57 & 0.62 & 0.61 & 0.67 & 0.64 & 0.75 & 0.74 & 0.61 & 0.26 \\
\hline Di & 0.73 & 0.68 & 0.72 & 0.72 & 0.71 & 0.70 & 0.68 & 0.64 & 0.68 & 0.37 \\
\hline \multicolumn{11}{|c|}{ 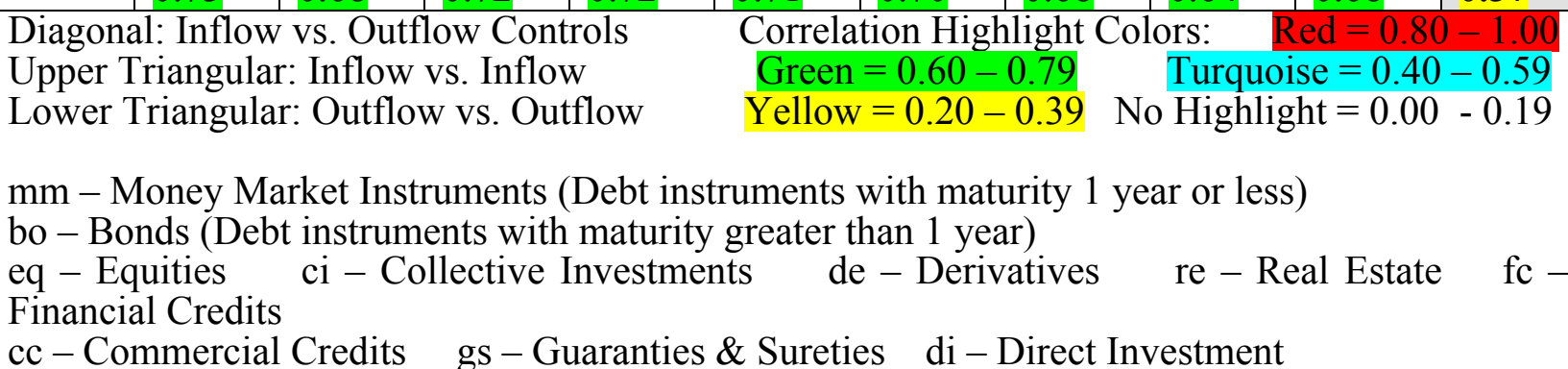 } \\
\hline
\end{tabular}

categories. Zero variances would be more prevalent if we first calculated correlations for each country, that is the correlation of $\mathrm{x}(i, t)$ and $\mathrm{y}(i, t)$ where $i$ represents a country, and then take the average of these correlations across countries to calculate the overall correlation. 
The table shows that the correlation between inflow controls and outflow controls for a given asset tends to be high. The highest correlation between inflow and outflow controls is for Derivatives (86 percent) and the lowest is for Direct Investment (37 percent) and Real Estate (30 percent). This result echoes that obtained by Fernández, Rebucci and Uribe (2014), who show that the cyclical components of capital controls on inflows and outflows are positively correlated. The correlation between asset categories, for both inflow controls and outflow controls, is highest among Money Market Instruments, Bonds, Equities, Collective Investments, and Derivatives. The lowest correlations are found for inflow controls between Real Estate and each of the other nine categories of assets. More broadly, the correlations are higher among the asset categories for outflow controls than for inflow controls.

Countries that had almost no controls for any category over the entire sample period, as well as countries that had controls on virtually all assets in every year, will contribute to larger values of the correlations in Table 4. We call these Open countries and Wall countries, respectively, following Klein (2012). In particular, the 36 countries in the Open category (which includes 24 of the 42 High Income countries) each had capital controls on less than 15 percent of their asset/direction categories over the sample period and had no year in which capital controls were in place on more than 25 percent of the categories. The 16 countries in the Wall category (which includes 11 of the 26 Lower Middle Income and Low Income countries) each had controls on at least 70 percent of their asset/transaction categories and had no year in which capital controls were in place on less than 60 percent of the categories. The 48 countries that are neither Open nor Wall are classified as Gate countries. As mentioned above, Table 1 notes the classification of each country in terms of these three categories.

Table 5A presents the correlations across asset/direction categories for the 48 Gate countries and Table 5B presents these correlations for the 52 Open and Wall countries. As expected, the correlations for the Gate countries are lower than those of the other countries, with only one greater than 80 percent (red cell) and 40 less than 40 percent (yellow cells, and cells without highlighting). In contrast, all the correlations in Table 5B among outflows are greater than 80 percent, and the majority of those among inflows (but for correlations with real estate) greater than 60 percent, with a fifth of the inflow restriction correlations greater than 80 percent. 
Table 5A. Cross-Category Correlations, 47 Gate Countries, 1995-2013

\begin{tabular}{|c|c|c|c|c|c|c|c|c|c|c|}
\hline & $\mathrm{mm}$ & bo & $\mathrm{Eq}$ & $\mathrm{Ci}$ & De & re & fc & cc & gs & $\mathrm{di}$ \\
\hline $\mathrm{mm}$ & 0.69 & 0.65 & 0.55 & 0.66 & 0.69 & 0.03 & 0.47 & 0.27 & 0.26 & 0.29 \\
\hline bo & 0.71 & 0.58 & 0.55 & 0.46 & 0.54 & 0.01 & 0.30 & \begin{tabular}{|l|}
0.11 \\
\end{tabular} & \begin{tabular}{|l|}
0.24 \\
\end{tabular} & 0.23 \\
\hline $\mathrm{eq}$ & 0.67 & .81 & 0.55 & 0.51 & 0.43 & 0.22 & 0.30 & 0.10 & \begin{tabular}{|l|}
0.27 \\
\end{tabular} & 0.44 \\
\hline $\mathrm{ci}$ & 0.77 & 0.75 & 0.70 & 0.60 & 0.57 & -0.01 & 0.46 & 0.33 & 0.35 & 0.41 \\
\hline de & 0.76 & 0.70 & 0.63 & 0.64 & 0.79 & -0.03 & 0.43 & 0.15 & 0.18 & 0.19 \\
\hline re & 0.57 & 0.43 & 0.44 & 0.52 & 0.54 & 0.08 & -0.02 & -0.07 & 0.01 & 0.24 \\
\hline $\mathrm{fc}$ & 0.50 & 0.42 & 0.41 & 0.45 & 0.51 & 0.43 & 0.48 & 0.59 & \begin{tabular}{|l|}
0.43 \\
\end{tabular} & 0.27 \\
\hline $\mathrm{cc}$ & 0.39 & 0.23 & 0.24 & 0.23 & 0.38 & 0.33 & 0.55 & 0.46 & 0.36 & 0.27 \\
\hline gs & 0.41 & 0.29 & 0.31 & 0.31 & 0.46 & 0.41 & 0.65 & 0.60 & \begin{tabular}{|l|}
0.44 \\
\end{tabular} & 0.17 \\
\hline di & 0.54 & 0.50 & 0.51 & 0.54 & 0.51 & 0.56 & 0.52 & 0.38 & 0.50 & 0.22 \\
\hline \multicolumn{11}{|c|}{ 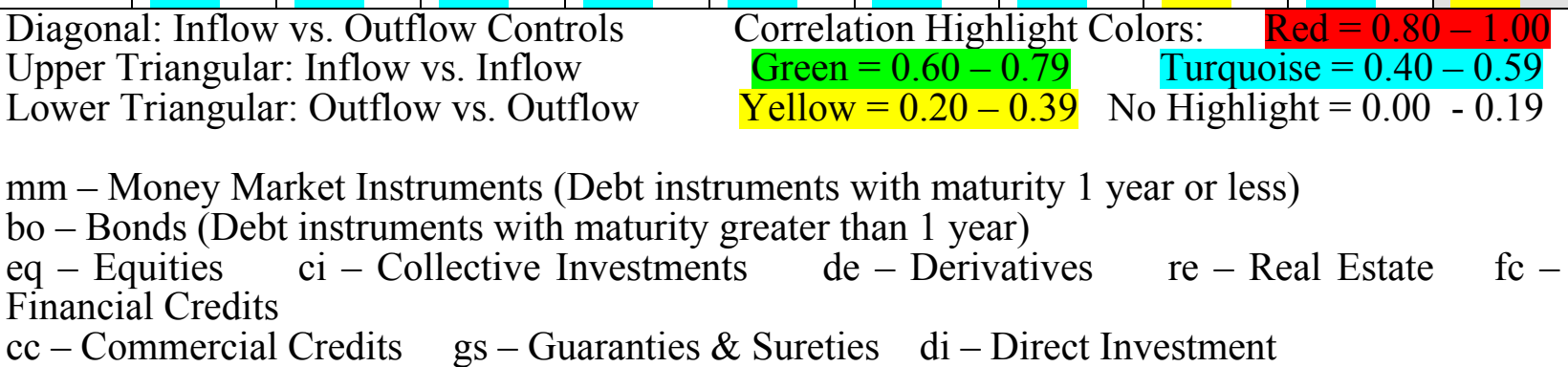 } \\
\hline
\end{tabular}

Table 5B. Cross-Category Correlations, 53 Open and Wall Countries, 1995-2013

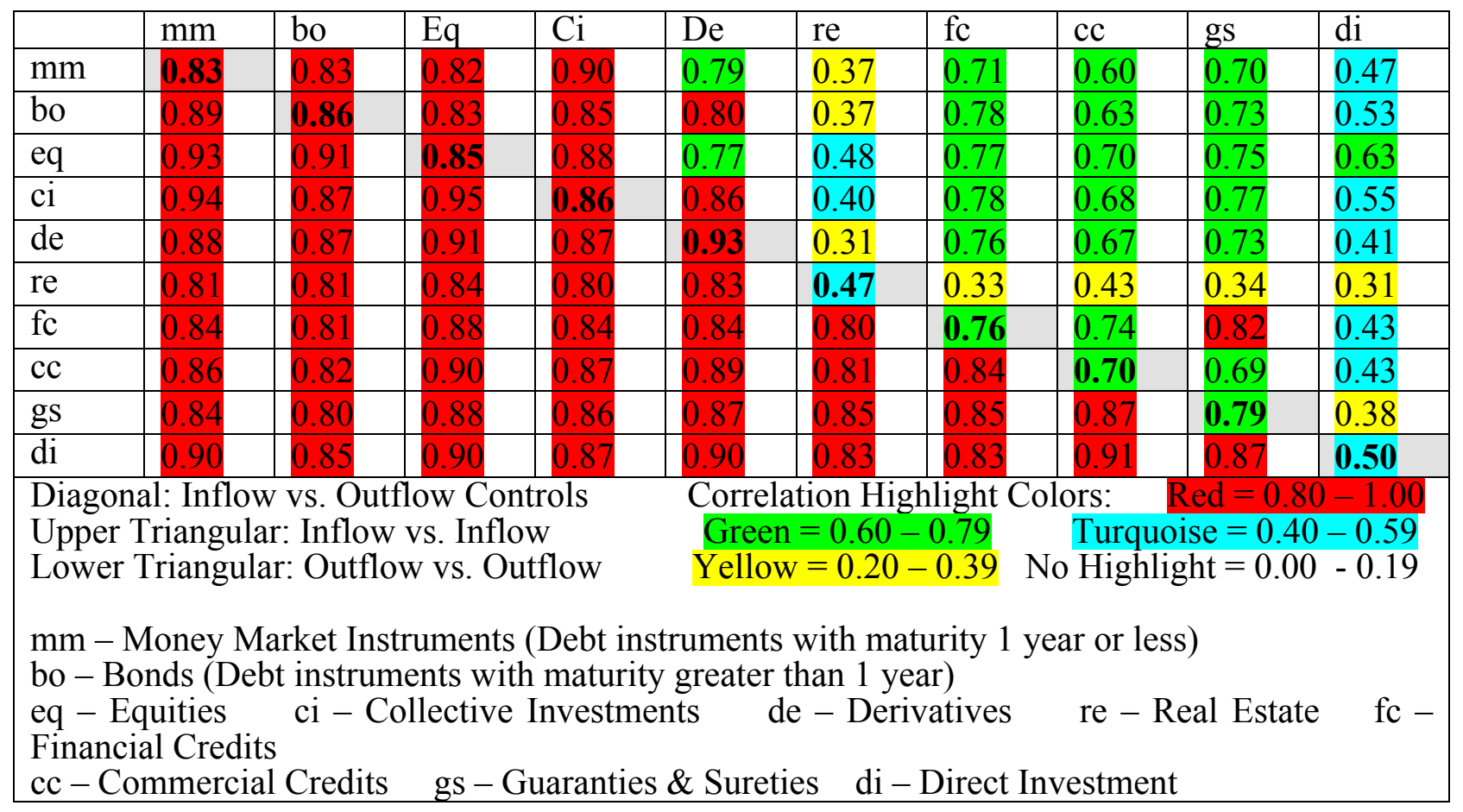


Correlations in controls for the subset of Gate countries are a better indicator of the manner in which countries pair controls used episodically than the correlations for the full set of countries. The highest correlations for the Gate countries are those between outflow controls on Money Market Instruments, Bonds, Equities, Collective Investments and Derivatives. The lowest correlations are those for inflow controls with Commercial Credits, and Real Estate. These patterns of correlations will inform our decisions on which asset categories to use when constructing aggregate capital control indices, which is the topic of the next section.

\section{Aggregate IndicAtors}

The correlations presented in Tables 4 and 5 are based on disaggregated asset/direction categories (with averages used for the categories that have two components for either inflows or outflows). In many instances it may be desirable to have a more aggregated indicator. For instance, one might be interested in studying the intensity with which capital controls are applied. By tracking variations across asset categories, directions of transactions, and time, aggregate indices capture a form of intensity of restrictions on capital movements across borders. Indeed, Fernández, Uribe and Rebucci (2014) show that an aggregate index of controls on capital inflows captures well the evolution of actual tax rates on capital inflows in the emblematic case of Brazil in the late 2000s. In this section we present a number of aggregate indicators and use them to demonstrate some characteristics of the capital control data.

An aggregate of the capital control indicators is important for presenting the evolution of capital controls over time; a graph of the 32 disaggregated capital control categories would be hopelessly muddled. Therefore, we first calculate two broad indicator of the stance of each country towards capital controls, one as the average value controls on inflows for the 10 asset categories in each year,

$K C_{i, t}^{I N F L O W}=\frac{1}{10} \sum_{j=1}^{10} X X_{i, j, t}^{I N F L O W}$

and another as the controls on outflows,

$K C_{i, t}^{\text {OUTFLOW }}=\frac{1}{10} \sum_{j=1}^{10} X X_{i, j, t}^{\text {OUTFLOW }}$ 
where $X X_{i, j, t}^{I N F L W}$ represents controls on inflows of the $j^{\text {th }}$ asset category (e.g., Money Market Instruments, Bonds, etc.) for the $i^{\text {th }}$ country in year $t$, and $X X_{i, j, t}^{\text {OUTFLOW }}$ is the comparable control on outflows of the $j^{\text {th }}$ asset category for the $i^{\text {th }}$ country in year $t$. We cannot plot the evolution for all 100 countries, however, so we take the average value for each of the four income groups; High, Upper Middle, Lower Middle and Low. Figures $2 \mathrm{a}$ and $2 \mathrm{~b}$ present the plots of these four aggregate series for controls on inflows and controls on outflows, respectively.

Figures $2 \mathrm{a}$ and $2 \mathrm{~b}$ show that, on average, the capital control index is inversely related to income. Specifically, the left axis in each figure is for the High Income group, and its midpoint is about 0.15 in Figure 2a and 0.17 in Figure $2 \mathrm{~b}$ while midpoints of the right axes, which pertain to the other three groups, is about 0.53 and 0.60 , respectively. This difference is not surprising, given the relatively large proportion of High Income countries that are classified as Open, and the relatively higher proportion of countries in the other three groups that are classified as Gate or Wall countries. This is also consistent with the findings of Fernandez, Uribe and Rebucci (2014), who found an inverse relation between capital controls and income levels, although their findings came from a more limited sample in terms of assets, countries and years.

Figure 2a: Average Controls on Inflows by Income Group Averages Across 10 Asset Categories

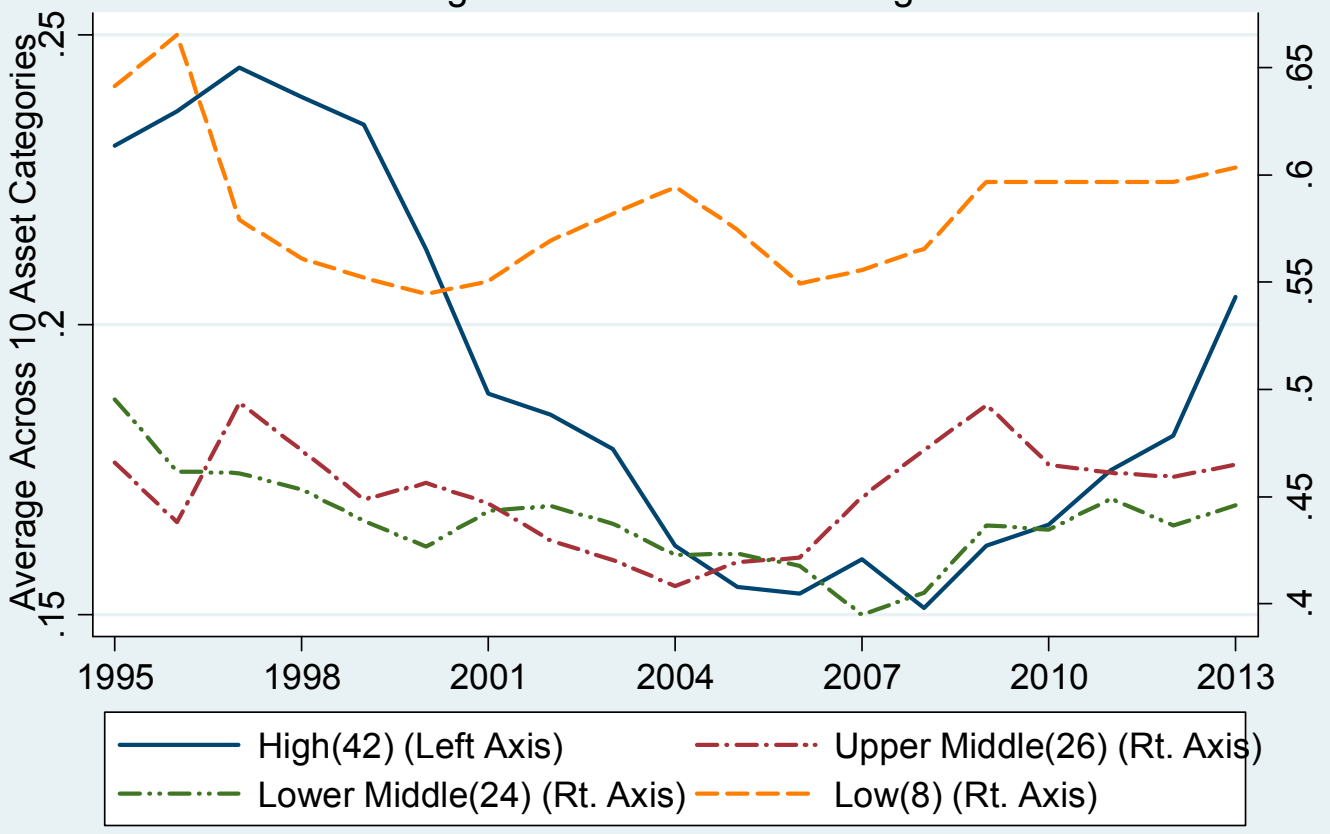


Figure 2b: Average Controls on Outflows by Income Group Averages Across 10 Asset Categories

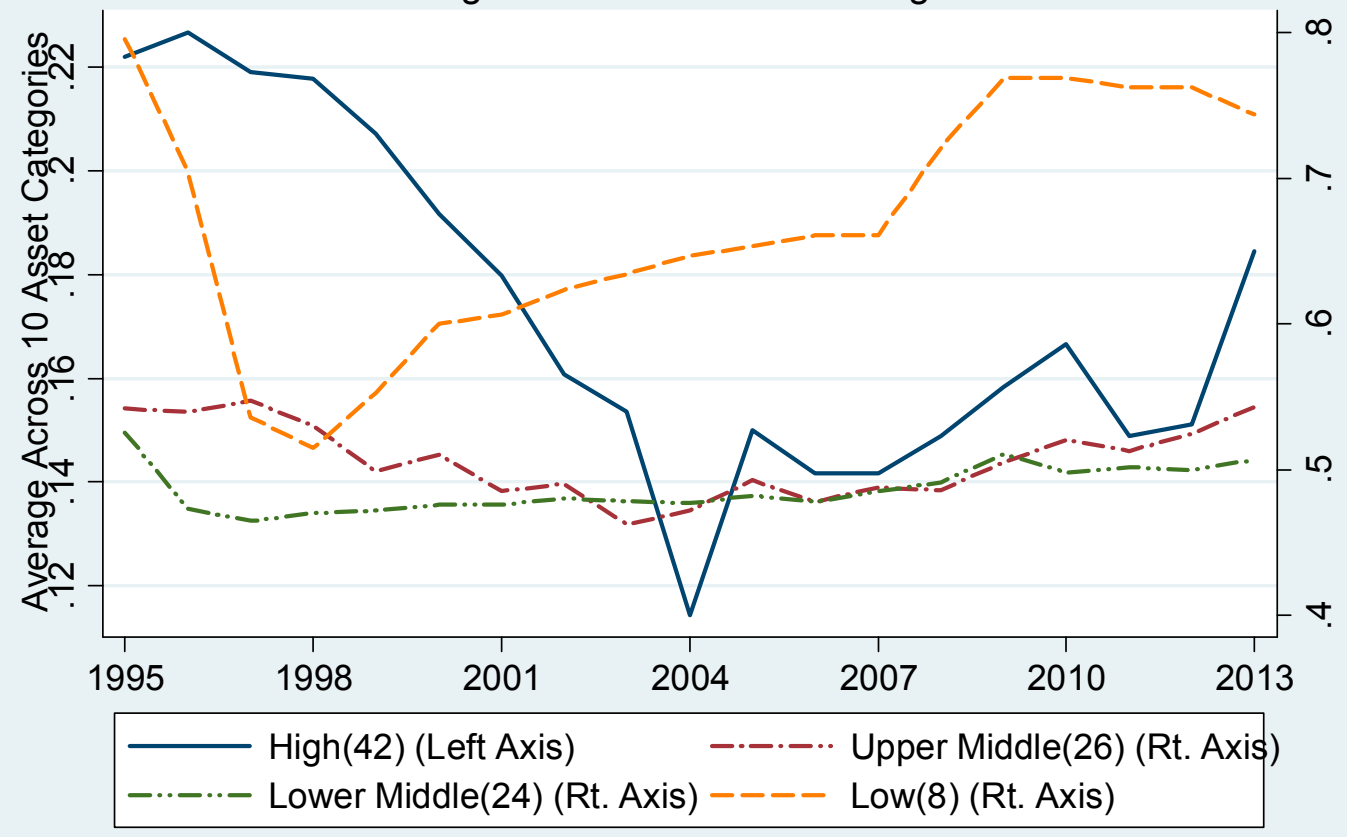

Another distinction across the income groups is the pattern of average capital controls over time. The High Income group of countries has a large decrease in its average from about 0.20 for inflows and 0.22 for outflows in the first years of the sample period to less than 0.10 in 2008 for inflows and 0.12 in 2004 for outflows before rising again in the subsequent years. The Low Income countries as a group also see a large decline in their average inflow and outflow controls in the first years of the sample period, and then an increase, especially in average controls on outflows. The range of the averages across time for both inflow controls and outflow controls for the two Middle Income groups is lower than the other groups, and the averages themselves are lower than the Low Income group but more than twice as high as those for the High Income group.

The aggregate indicators used to generate Figures $2 \mathrm{a}$ and $2 \mathrm{~b}$ show some differences between controls on inflows and controls on outflows. We further consider the relationship between inflow controls and outflow controls by calculating, for each country, its average controls on inflows and outflows over the full sample period, $\mathrm{KC}^{\mathrm{INFLOW}}{ }_{i}$ and $\mathrm{KC} \mathrm{OUTFLOW}_{i}$, respectively. These are defined as 
$K C_{i}^{I N F L O W}=\frac{1}{19} \sum_{t=1995}^{2013} \sum_{j=1}^{10} X X_{i, j, t}^{I N F L O W}$

$K C_{i}^{\text {OUTFLOW }}=\frac{1}{19} \sum_{t=1995}^{2013} \sum_{j=1}^{10} X X_{i, j, t}^{\text {OUTFLOW }}$

Figure 3 presents the scatterplots of these country-by-country indicators (along with a 45degree line), with the left panel representing the 42 High income countries and the right panel representing the 58 Medium and Low Income countries. The sizes of the bubbles in these figures reflect the number of countries in a small range.
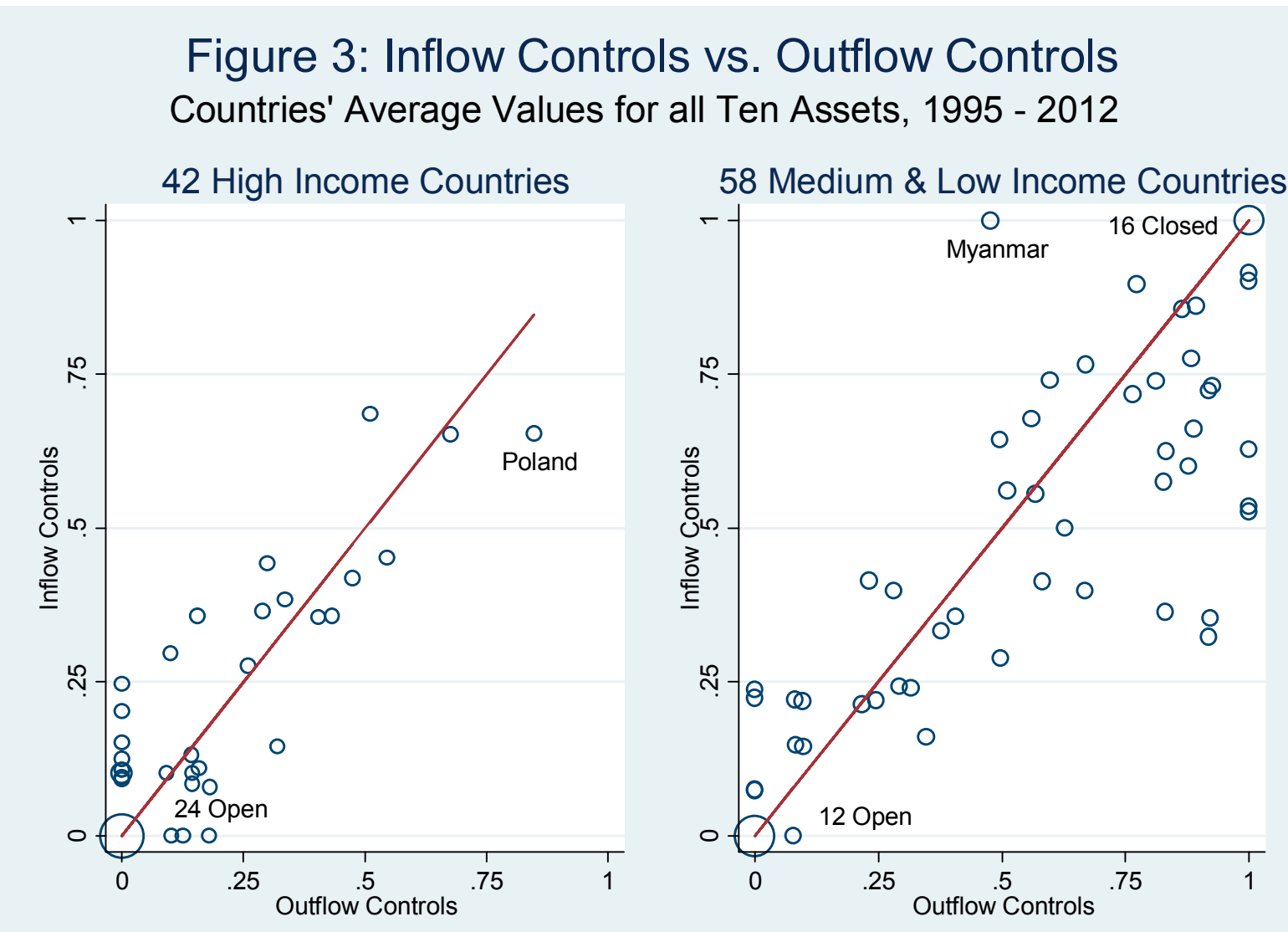

The two panels of this figure show a somewhat higher prevalence of outflow controls than of inflow controls, consistent with the statistics in Table 3 and Figure 1. Figure 3 illustrates that the difference in the prevalence of inflow and outflow controls is more pronounced for the Medium and Lower Income countries than for the High Income countries. The two panels of 
Figure 3 also show that there is a relatively high correlation of inflow and outflow controls on a country-by-country basis (for both sets of countries, the correlation is about 0.8). This is necessarily the case for the 36 Open countries and, to a somewhat lesser extent, for the 16 Wall countries.

Figures 2 and 3 use aggregates either across sets of countries for each year or across time for each country. In some cases we may want to take advantage of the detailed nature of the data set and have an aggregate indicator based on a subset of assets; for example, Klein and Shambaugh (2015) use an indicator that includes only Money Market Instruments and Bonds in their analysis of interest parity as well as another indicator that includes those asset categories plus Equities, Collective Investment and Financial Credits.

More generally, with any aggregate we would want to consider the benefit of having a single measure against the cost of masking information by combining possibly disparate series. An aggregate indicator will be more representative of its constituent series if the series are more highly correlated with each other. For example, an aggregate indicator averaging the inflow and outflow series for Derivatives is more representative of its two constituent parts than one that averages the inflow and outflow indicators of Real Estate since the correlation of the former is 0.86 and that of the latter is 0.30. Likewise, an aggregate of the outflow controls for Money Market Instruments, Bonds, Equities and Collective Investments would be one that is relatively representative of each of these separate categories since each of the six pairwise correlations is greater than 80 percent, while the broadening of this aggregate to include controls on Commercial Credits would be less representative since the correlations of that category with the other four range from 55 percent to 64 percent.

We begin by examining the correlation between the average of inflows and outflows of a single asset with that of an average of an aggregate of the inflows and outflows of the other nine assets. Table 6 presents this set of ten statistics. The table shows that controls on Real Estate, Commercial Credits, Direct Investment, and Guarantees, Sureties, and Financial Backup Facilities are least correlated with the aggregate of the respective nine remaining categories while the correlation of Money Market Instruments, Collective Investments, Derivatives and Equities are most highly correlated. 
Table 6. Correlation between Nine-Asset Aggregate Capital Controls and Excluded Asset Category

\begin{tabular}{|c|c|c|c|c|c|c|c|c|c|c|}
\hline Excluded Asset & $\mathrm{mm}$ & bo & eq & $\mathrm{Fc}$ & $\mathrm{ci}$ & de & re & $\mathrm{cc}$ & gs & di \\
\hline Correlation & 0.87 & 0.83 & 0.87 & 0.83 & 0.88 & 0.87 & 0.61 & 0.71 & 0.79 & 0.77 \\
\hline
\end{tabular}

We next consider a set of nested aggregate indicators that differ by the number of component assets (again, each asset series represents the average of inflow and outflow controls). All 10 assets are included in the broadest indicator, $K C 10_{i, t}$, which is the average of the inflow and outflow indicators above,

$K C 10_{i, t}=\frac{1}{20} \sum_{j=1}^{10} X X_{i, j, t}^{I N F L O W}+\frac{1}{20} \sum_{j=1}^{10} X X_{i, j, t}^{\text {OUTFLOW }}$

The series $K C 9_{i, t}$ excludes direct investment, both because it is less correlated with the other assets than almost any other series and because controls on direct investment often reflect noneconomic considerations. The series $K C 5_{i, t}$ includes Money Market Instruments, Bonds, Equities, Collective Investments, and Derivatives, five series that are relatively highly correlated. The narrowest category, $K C 2_{i, t}$, includes only controls on fixed income assets, Money Market Instruments and Bonds.

Table 7 presents the correlations across these categories for the full set of countries (the six upper triangular elements of the table) and the Gate countries only (the six lower triangular elements) for these four aggregate indicators. The correlations are very high for the full set of countries, with a range from 0.924 (for the correlation between $\mathrm{KC10}$ and $\mathrm{KC} 2$ ) to 0.995 (for the correlation between $\mathrm{KC} 9$ and $\mathrm{KC10}$ ). The correlations among these aggregates for the Gate countries are, naturally, lower than the respective correlations for the full set of countries, and there is also a greater range of values. For example, the correlation between the two-asset and 10 -asset indicators is 0.873 . In contrast, the difference in the correlation of the two-asset and five-asset indicators between the full sample (0.971) and the sample of Gate countries (0.953) is not nearly as large. Thus, there could be differences in the estimated effect of capital controls in an analysis in which the identification depends upon the pattern of controls for Gates countries. 
Table 7. Correlations among Aggregate Capital Controls Measures

\begin{tabular}{|l|l|l|l|l|}
\hline & KC10 & KC9 & KC5 & KC2 \\
\hline KC10 & & 0.995 & 0.954 & 0.924 \\
\hline KC9 & 0.992 & & 0.958 & 0.928 \\
\hline KC5 & 0.901 & 0.910 & & 0.971 \\
\hline KC2 & 0.873 & 0.877 & 0.953 & \\
\hline KC10: Avege
\end{tabular}

KC10: Average of Inflows and Outflows for mm, bo, eq, ci, de, re fc, cc, gs, di.

KC9: Average of Inflows and Outflows for mm, bo, eq, ci, de, re fc, cc, gs (all but di).

KC5: Average of Inflows and Outflows for $\mathrm{mm}$, bo, eq, ci, de.

$\mathrm{KC}$ : Average of Inflows and Outflows for $\mathrm{mm}$, bo.

Upper triangular elements show correlations among all 100 countries.

Lower triangular elements show correlations among 48 Gate countries.

We conclude this section by considering the relationship between the average for each country of our broadest indicator of capital controls, $\mathrm{KClO}_{i}$ and the average, over the same time periods, of two popular measures of aggregate capital controls that have been used in empirical research. The index developed by Quinn (1997) attempts to capture the intensity of enforcement of controls on both the capital account and the current account. As in the present study, Quinn derives an index of capital controls from the narrative portion of the AREAER reports. To assess the severity of the restrictions on capital flows, Quinn's index uses a five-point scale at the granular level. However, his index does not distinguish between capital controls on inflows and capital controls on outflows. For purposes of comparison to our aggregate index, in the analysis below we convert his capital account index to the range $[0,1]$ in which, as with our index, larger values represent more restrictions on capital account transactions. The Chinn-Ito index (first presented in Chinn and Ito, 2006) takes the first principal component of the AREAER summary binary codings of controls relating to current account transactions, capital account transactions, the existence of multiple exchange rates, and the requirements of surrendering export proceeds. As with the Quinn index, we convert this index to one with the range $[0,1]$ in which larger values represent more restrictions, to facilitate comparison with our index. 
We regress the average value for each country of each of these two indices over the sample period on the average value for each country of our broad indicator of capital account controls, $\mathrm{KC10}{ }_{\mathrm{i}} \cdot{ }^{19}$ These estimates, with the standard errors given in parentheses, are

$$
\begin{gathered}
\text { Quinn }_{i}=0.004_{(0.019)}+0.71_{(0.041)} K C 10_{i} \quad R^{2}=0.77 ; n=90 \\
\text { ChinnIto }_{i}=0.049_{(0.025)}+0.91_{(0.051)} K C 10_{i} \quad R^{2}=0.77 ; n=99 .
\end{gathered}
$$

Plots of the regression lines, and the scatter plots of the points, are presented in the two panels of Figure 4. We identify the country associated with each point for which the absolute value of the regression error is greater than 0.25 for the regression for the Quinn indicator, and 0.20 for the Chinn-Ito regression.

In both of these regressions, the coefficient on $\mathrm{KC} 10_{\mathrm{i}}$ is significantly different from zero at very high levels of confidence. But the more relevant test is whether these coefficients are significantly different from 1 . The t-statistic for this test in the regression with the Chinn-Ito indicator is 1.71 and the t-statistic for the Quinn regression is 7.21. Thus, the null hypothesis that the coefficients equal 1 can be rejected at the 95 percent level of confidence in both cases, but not at the 90 percent level of confidence in the case of the Chinn-Ito indicator.

\footnotetext{
${ }^{19}$ The average values of $\mathrm{KC} \mathrm{O}_{\mathrm{i}}$ used in the regressions are calculated using annual data only for those countries that have data for the Quinn and the Chinn-Ito indices in the respective years (the averages $\mathrm{KC} 10_{\mathrm{i}}$ are different for the Quinn and Chinn-Ito regressions since these two indices have different country coverage in each year). The sample period used to calculate these averages is 1995 to 2012.
} 


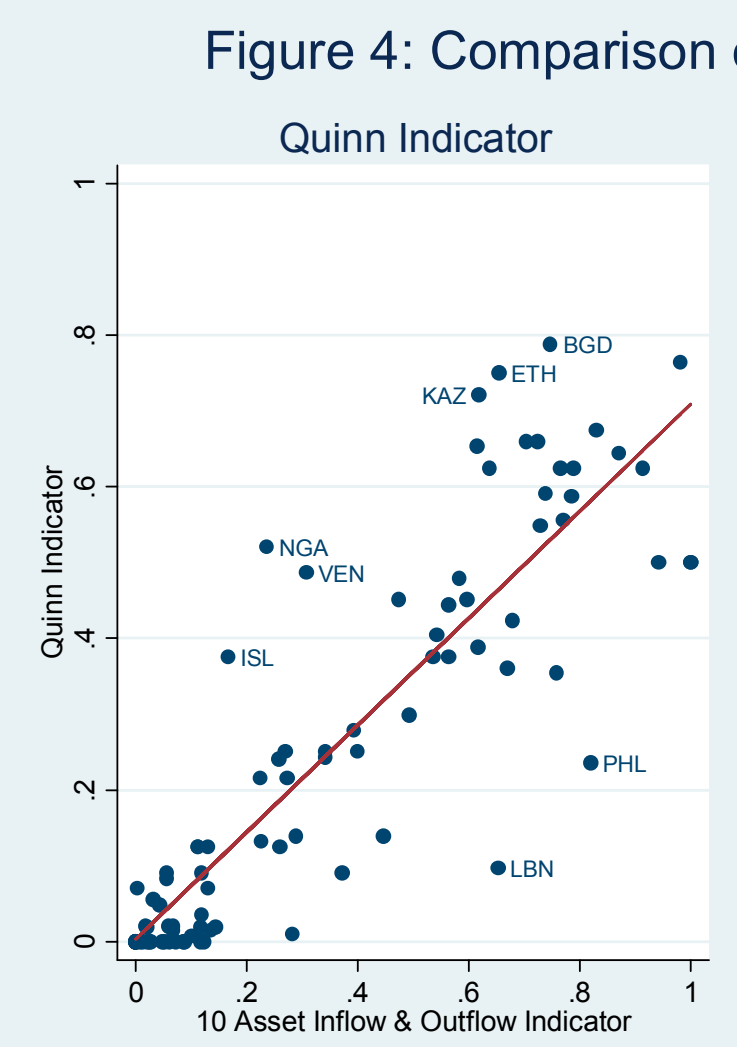

of Aggregate Indicators

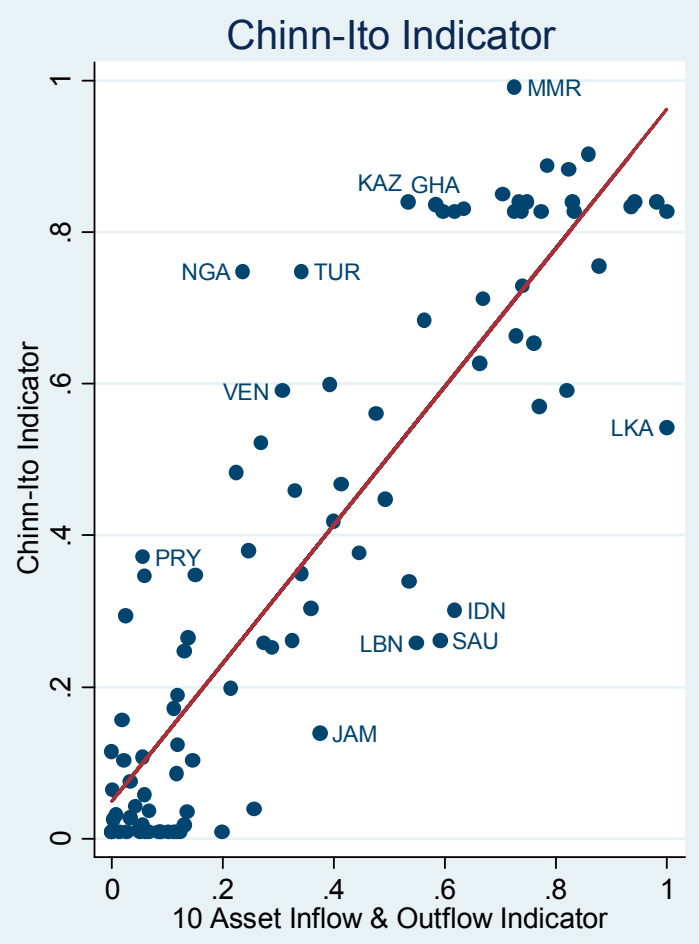

\section{Conclusions}

The role that capital controls should play in countries' macroeconomic toolkits remains one of the most hotly contested issues in discussions on the international monetary system. The shift among some policymakers and researchers towards a greater acceptance of these rules and regulations in the wake of the economic and financial turmoil of the past few years contrasts with the views of others that many of these policies are ineffective and cause unintended consequences. Properly addressing the continuing controversies surrounding this topic requires careful, high-quality theoretical and empirical research.

We contribute to this debate by making available a new dataset, described in this paper, which will enable more detailed and wider-ranging empirical investigations of capital controls and their effects. In this paper we have illustrated and explained the data construction. We also present some of the basic properties of the granular data as well as those of aggregates built up 
from the individual data series. Our hope is that this dataset proves useful in moving forward our understanding of this important topic. 


\section{REFERENCES}

Bhagwati, J. 1998. "The Capital Myth: The Difference between Trade in Widgets and Trade in Dollars." Foreign Affairs 77: 7-12.

Benigno, G. et al. 2014. "Optimal Capital Controls and Exchange Rate Policy? A Pecuniary Externality Perspective.” CEPR Discussion Paper 9936. London, United Kingdom: Centre for Economic Policy Research.

Bianchi, J. 2011. "Overborrowing and Systemic Externalities in the Business Cycle." American Economic Review 101(7): 3400-3426.

Binici, M., M. Schindler and M. Hutchison. 2010. "Controlling Capital? Legal Restrictions and the Asset Composition of International Financial Flows." Journal of International Money and Finance 29(4): 666-684.

Chinn, M.D., and Hiro Ito. 2006. "What Matters for Financial Development? Capital Controls, Institutions, and Interactions." Journal of Development Economics 81(1): 163-192.

----. 2008. “A New Measure of Financial Openness.” Journal of Comparative Policy Analysis 10: 309-22.

De Gregorio, J., S. Edwards and R. Valdés. 2000. "Controls on Capital Inflows: Do They Work?" Journal of Development Economics 69: 59-83.

Dornbusch, Rudiger. 1998. "Capital Controls: An Idea Whose Time is Gone." Cambridge, United States: Massachusetts Institute of Technology. Mimeographed document.

Farhi, E., and I. Werning. 2012. "Dealing with the Trilemma: Optimal Capital Controls with Fixed Exchange Rates.” NBER Working Paper 18199. Cambridge, United States: National Bureau of Economic Research.

Fernández, A., A. Rebucci and M. Uribe. 2014. “Are Capital Controls Countercylical?” New York, United States: Columbia University. Mimeographed document.

Forbes, K. 2007. "One Cost of Chilean Capital Controls: Increased Financial Constraints for Smaller Traded Firms." Journal of International Economics 71: 294-323.

Forbes, K. et al. 2012. "Bubble Thy Neighbor: Direct and Spillover Effects of Capital Controls." NBER Working Paper 18052. Cambridge, United States: National Bureau of Economic Research. 
Grilli, V., and G-M. Milesi-Ferretti. 1995. "Economic Effects and Structural Determinants of Capital Controls." IMF Staff Papers 42(3): 517-51.

IMF Strategy, Policy and Review Department. 2011. "Recent Experiences in Managing Capital Inflows: Cross-Cutting Themes and Possible Policy Framework." Washington, DC, United States: International Monetary Fund. Available at: http://www.imf.org/external/np/pp/eng/2011/021411a.pdf

Jeanne, O. 2012. "Capital Flow Management." American Economic Review Papers and Proceedings 102(3): 203-06.

Jeanne, O., A. Subramanian and J. Williamson. 2012. Who Needs to Open the Capital Account? Washington, DC, United States: Peterson Institute for International Economics.

Keynes, J.M. 1920. The Economic Consequences of the Peace. New York, United States: Harcourt, Brace and Howe.

Klein, M.W. 2012. "Capital Controls: Gates versus Walls." Brookings Papers on Economic Activity 2012 (Fall): 317-355.

Klein, M.W. and J. Shambaugh. 2015. "Rounding the Corners of the Policy Trilemma: Sources of Monetary Policy Autonomy." Forthcoming in American Economic Journal: Macroeconomics.

Korinek, A. 2010. "Regulating Capital Flows to Emerging Markets: An Externality View." College Park, United States: University of Maryland. Mimeographed document.

Lane, P., and G-M. Milesi-Ferretti. 2007. "The External Wealth of Nations Mark II.” Journal of International Economics 73: 223-250.

Miniane, J. 2004. "A New Set of Measures on Capital Account Restrictions." IMF Staff Papers 51:276-308.

Ostry, J. et al. 2010. "Capital Inflows: The Role of Controls." IMF Staff Position Note SPN/10/04. Washington, DC, United States: International Monetary Fund.

Ostry, J. et al. 2011. "Capital Controls: When and Why." IMF Economic Review 59(3): 562-580.

Prati, A., M. Schindler and P. Valenzuela. 2012. "Who Benefits from Capital Account Liberalization? Evidence from Firm-Level Credit Ratings Data." Journal of International Money and Finance 31(6): 1649-1673.

Quinn, D. 1997. "The Correlates of Change in International Financial Regulation." American Political Science Review 91(3): 531-51. 
Quinn, D., M. Schindler and A.M. Toyoda. 2011. "Assessing Measures of Financial Openness and Integration." IMF Economic Review 59(3): 488-522.

Rey, H. 2014. "Dilemma not Trilemma: The Global Financial Cycle and Monetary Independence." In: Global Dimensions of Unconventional Monetary Policy: A Symposium Sponsored By the Federal Reserve Bank of Kansas City, Jackson Hole, Wyoming, August 22-24, 2013. Kansas City, United States: Federal Reserve Bank.

Rodrik, D. 1998. “Who Needs Capital-Account Convertibility?” In: S. Fischer et al., editors. Should the IMF Pursue Capital Account Convertibility? Essays in International Finance 207. Princeton, United States: Princeton University, Department of Economics, International Finance Section.

Rogoff, K.S. 2002. "Rethinking Capital Controls: When Should We Keep an Open Mind?" Finance and Development 39(4): 55-56.

Schindler, M. 2009. "Measuring Financial Integration: A New Data Set." IMF Staff Papers 56(1): 222-38.

Schmitt-Grohé, S., and M. Uribe. 2012. "Prudential Policy for Peggers.” NBER Working Paper 18031. Cambridge, United States: National Bureau of Economic Research.

Skidelsky, R. 1992. John Maynard Keynes: The Economist as Saviour, 1920-1937. London, United Kingdom: Macmillan.

Tamirisa, N. 1999. "Exchange and Capital Controls as Barriers to Trade." IMF Staff Papers 46: 69-88. 